\title{
GÉPJÁRMỨ KANYARODÁSI TECHNOLÓGIÁK, KÖZVETLEN ADAPTÍV KORMÁNYZÁS
}

\section{VEHICLE STEERING TECHNOLOGIES, DIRECT ADAPTIVE STEERING}

\author{
Tuloki Szilárd ${ }^{1}$, Nagy István ${ }^{2}$ \\ I'Óbudai Egyetem, Bánki Donát Gépész és Biztonságtechnikai Mérnöki Kar; 1034 \\ Budapest, Bécsi út 96/B; tuszilard@gmail.com \\ ${ }^{2}$ Óbudai Egyetem, Bánki Donát Gépész és Biztonságtechnikai Mérnöki Kar; 1081 \\ Budapest, Népszínház u.8; Tel.: +36-1-666-5366,nagy.istvan@bgk.uni-obuda.hu
}

\begin{abstract}
The steering technologies have come a long way in the last decade. Our goal by this paper is to present the different types of vehicle's steering system, then a detailed introduction of the Direct Adaptive Steering (DAS). Direct adaptive steering is a completely new steering system from INFINITY, which utilizes 'steer by wire' technology. It was introduced first at 2013.

Keywords: Steering technologies, Direct Adaptive Steering, DAS,

\section{Összefoglalás}

A különböző kanyarodási technológiák jelentős fejlödésen mentek keresztül az elmúlt évtizedekben. Ebben a konferenciacikkben egy tanulmányt végzünk, melynek keretében az eddig használatos, elterjedt technológiák kerülnek bemutatásra, majd bővebben tárgyaljuk az INFINITY által bevezetett közvetlen, digitális alapú adaptív kormányzást.
\end{abstract}

Kulcsszavak: Kanyarodási technológiák, Közvetlen Adaptív Kormányzás, DAS,

\section{Introduction}

The basic requirement of a vehicle's steering system is to allow the driver to easily maintain the vehicle's position in high speed or in rough road surfaces. Because of this lots of different solutions are created to help the driver change the vehicle's path without much effort. Early vehicle systems were equipped with mechanical steering systems which had very low, or 1:1 steering ratios. These did not meet the criteria above, because they were heavy to use (in low speed especially) and had problems holding the vehicle in straight line at high speed. Because of these the first solution was to increase the steering ratio.

\section{Steering ratio}

Steering ratios gives mechanical advantages to the driver. It allows the wheel to be turned more easily, overcoming the vehicles weight. In another way it means that we don't have to turn the steering wheel a so many times to move the vehicles wheels.

Steering ratio is the relationship between the steering wheels rotation and the amount of the road wheels are turned. In general the higher the steering ratio, the easier to turn 
the vehicle wheels, but you need to turn the steering wheel more. The lower the steering ratio, the harder it is to turn the steering wheel, but you need to turn it less. Modern passenger vehicle with power assisted steering systems have steering ratios from 12:1 to 20:1. Most manufacturers use a steering rack and pinion to gain this ratio. When determining the final steering ratio of a new vehicle, we must take into consideration the vehicles Steering geometry, wheels and tires and the intent of use.

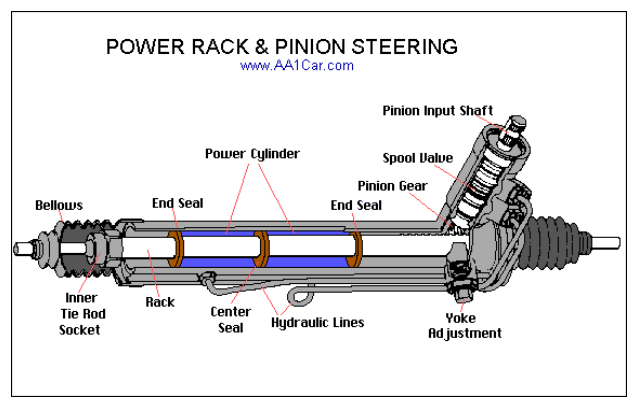

1. Figure Power rack \& pinion steering [1]

\section{Power Assisted Steering (PAS)}

The introduction of hydraulic power assisted steering was a great breakthrough, because it allowed the vehicle manufacturers to overcome the limitations of the earlier mechanical systems. In the past years lots of improvements have made, thanks to the new electric integration components.

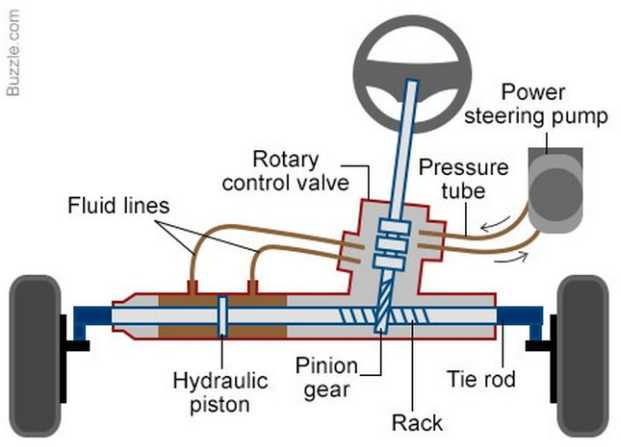

2. Figure Power assisted steering [2]

\section{Hydraulic Speed Sensitive Pow- er Steering (HPS)}

The major disadvantage of PAS systems is that it gives few assistances to the driver. When parking or maneuvering at low speed, we need higher assistance, but when we are driving with high speed then we need less assistance from the system. With a solenoid valve and a simple control module to the basic PAS system, we can archive a variable rate of assistance system. The system gathers information from the Engine and vehicle speed information is used by the power steering control module to manage the level of steering assistance provided. The power steering solenoid valve fitted to the side of the steering valve assembly is used to regulate the amount of fluid pressure from the steering fluid reservoir and pump.

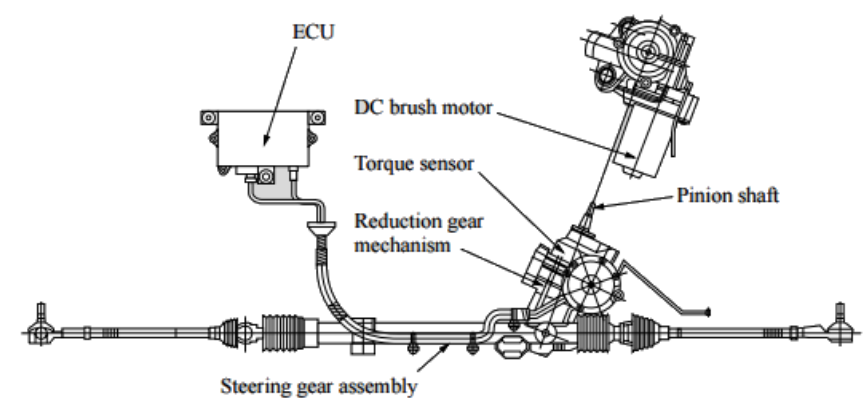

ECU: electronic control unit

3. Figure HPS [3] 
As the vehicle speed increases the voltage to the solenoid valve is reduced, limiting the oil pressure assistance to the steering rack. The rack is a fixed ratio type. For more detailed information on how the solenoid valve interacts with the internal operation of the PAS steering valve assembly, please refer to the relevant Steering Control System (STC) ESM.

\section{Four Wheel Active Steering (4WAS)}

The 4WAS system is able to alter the ratio of turns to the front steering and provide additional steering movement to the rear wheels. It works alongside other vehicle dynamic control systems to stabilize the car in a potential oversteer or understeer situation beyond the normally natural level of grip. It also provides an enhanced dynamic driving experience for the driver who will feel an additional level of agility in slalom type maneuvers.

By actively turning all four wheels as you steer, 4-Wheel Active Steer elevates handling and the very experience of each corner. The system adjusts steering angle and ratio to vehicle speed, creating a more responsive and fluid sense of control. With natural low-speed feel, responsive midspeed turn-in, and precise high-speed stability, 4-Wheel Active Steer makes cornering gracefully easy.

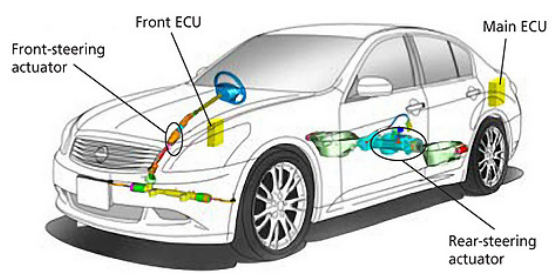

4. Figure $4 W A S[4]$

\section{Rear Active Steering (RAS)}

Rear Active Steering is similar in construction and operation to the rear wheel steering function of the 4WAS system. It is designed to improve low speed agility while providing high speed stability. The RAS works in conjunction with the HPS system. When the driver begins to turn the steering wheel the rear wheels momentarily move in the opposite direction to the front wheels to improve the yaw rate (steering angle speed).

Once the necessary yaw rate (steering angle speed) has been achieved, the rear wheels are turned in the same direction as the front wheels to improve the 'turn in' cornering response.
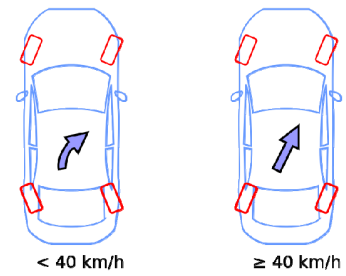

5. Figure RAS operation [5]

\section{Hybrid Electric Power Steering (HEPS)}

With the introduction of hybrid powertrain technology, a power steering system was required that could provide steering assistance without the engine running (when in electric mode). On the

HEPS system an electrically operated power steering pump assembly (circled), replaces the engine driven pump found on other hydraulic steering systems. It only operates when steering assistance is required.

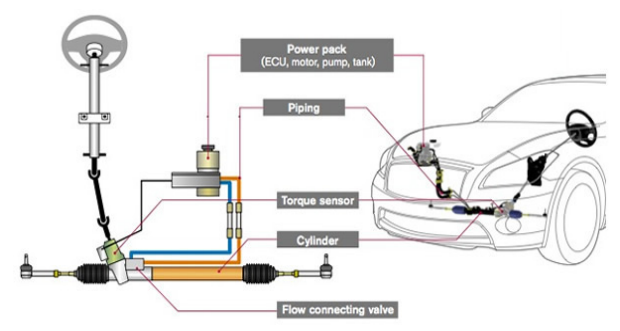

6. Figure HEPS [6] 
The control module uses vehicle speed and torque sensor steering force information to govern the output speed of the electric motor, which in turn varies the oil pump output pressure to control the amount of steering assistance. The electric motor can be rotated in either direction, depending on the direction input signal from the steering angle sensor. The flow connection valve is a safety device that is energized in the closed position whilst ever the system is functional.

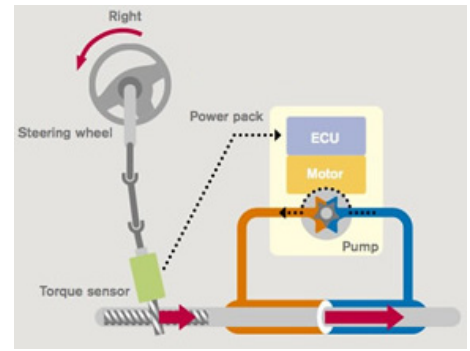

7. Figure HEPS operation [6]

\section{Direct Adaptive Steering (DAS)}

Direct adaptive steering is a completely new steering system, which were introduced by Infiniti. DAS removes the mechanical connection between the steering wheel and tires, allowing for instantaneous driver input that can be digitally processed and adjusted up to 1,000 times per second. It utilizes 'steer by wire' technology and is the world's first application on a production vehicle. The DAS is unaffected by the kickback and forced movement of conventional steering but still gradually requires more effort with increased speed and G-forces like a conventional system.

The steering wheel is normally (fault free) disengaged from the steering rack whenever the steering clutch is activated (ignition $\mathrm{ON}$ ). The system converts driver steering wheel inputs into electrical signals which are sent to different modules. Simulated feeling of the road is transferred to the steering wheel via the steering force actuator. If the vehicle has an active lane control feature, then the slight correction to the gear is applied via the steering angle actuators to improve the vehicle stability, for example if the vehicle direction is affected by other forces. Angle and torque sensors fitted to the steering wheel, steering force actuator, steering rack and steering angle actuators ensure system integrity.

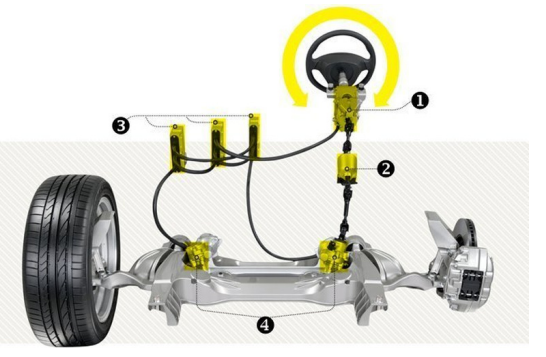

8. Figure 'steer by wire': 1.Steering force sensor; 2.Clutch; 3.Control modules 4; Steering assist motors

To ensure system integrity is maintained, the DAS system utilizes a triple redundancy protocol that enables the three DAS control modules to share each other's information at all times via its dedicated Flex Ray communication network. The Flex Ray network data transfer speed is considerably faster than CAN and therefore gives near instantaneous processing power.

\section{References}

[1] http://www.aal car.com/library/2003 bf20340.htm

[2] http://www.toyotazone.co.za/ howitworks/power-steering-fault-diagnosis/

[3] http://www.hitachi-automotive.us/Products/ oem/DCS/Steering/index.htm

[4] http://articles.sae.org/3323/

[5] https://en.wikipedia.org/wiki/ Steering\#/media/File:4WSselect.svg

[6] http://www.nissan-global.com/en/ technology/overview/ehpss.html

[7] http://www.caranddriver.com/features/ electric-feel-nissan-digitizes-steering-but-thewheel-remains-feature

[8] http://www.infinitiusa.com/

[9] http://www.nissan-global.com/ 